\title{
STAMBP wt Allele
}

National Cancer Institute

\section{Source}

National Cancer Institute. STAMBP wt Allele. NCI Thesaurus. Code C52457.

Human ST AMBP wild-type allele is located in the vicinity of 2p13.1 and is approximately $44 \mathrm{~kb}$ in length. This allele, which encodes STAM-binding protein, plays a role in both Myc signaling pathway initiation and cell cycle progression. 